\title{
千里ニュータウンにおける集合住宅団地の建替えによる緑地構造の変化に関する研究
}

\section{Study on Changes in Structure of Open Spaces Due to Housing Complex Reconstruction in Senri New Town}

田中 陽大* 加我 宏之* 下村 泰彦* 増田 昇*

\author{
Akihiro TANAKA Hiroyuki KAGA Yasuhiko SHIMOMURA Noboru MASUDA
}

\begin{abstract}
In this study, we investigated changes in quantity and function of open spaces before and after housing complex reconstruction in the areas of Senri New Town where there were concentrations of rebuilt housing complexes, and sought out the challenges in open space renovation accompanying housing complex rehabilitation. The results revealed that, in the areas where suppliers of rebuilt housing complexes changed from the public sector to the private sector, both the total area of green spaces and the ratio of green coverage were the same as before the reconstruction of housing complexes. The area of greenery on natural ground and the ratio of tree coverage decreased, while those on artificial ground increased. In the areas where the public sector rebuilt housing complexes, the openness of open spaces remained intact, but their availability declined because of the drastic decrease in green area and the subdivision of open squares after the reconstruction.
\end{abstract}

Keywords: housing complex reconstruction, new town renovation, structure of open spaces キーワード: 建替え団地, ニュータウン再生, 緑地構造

\section{1. はじめに}

日本最初の大規模ニュータウンである千里ニュータウンは，公 園・緑地に加えて集合住宅団地内の緑地が豊かに育まれ，良好な 居住環境を形成している。しかし，現在，千里ニュータウンは， 開発後約 50 年が経過する中，住民の年齢構成の変化，二ュータ ウン周辺の都市化, 地域商業の衰退等の問題が指摘され, その中 でも建物の老朽化などによる住宅更新が活発化し，建替えに伴う 様々な空間変容が起きている。ニュータウンの魅力を持続しつつ, 新たな居住ニーズに対応したニュータウンの再生に際して，千里 ニュータウン再生指針 1)では，住宅更新において緑地の保全・継 承に加えて緑地の発展がより重要であるとしている。

集合住宅団地の建替えに伴う空間や緑環境の変容に関する既往 研究を見ると, 加我(2004)2) らは, 建替え後に居住者が好むs樹木を 建替え後に現地保存し，また，建替え時の樹木選定に際して保存 樹のイメージを継承しながら移植樹木や新規樹木を選定すること が居住者の団地空間に対する愛着を継承することに効果的である と述べている。武田(2010)3) らは, 高齢者などの日常生活者が緑化 活動などの屋外空間の使いこなしを通じて，歩いて生活できる圈 域内に系統的に整備されているオープンスペースの価值を向上さ せることで，ニュータウン再生に資する郊外居住の新たな魅力の 創出につながると述べている。また, 河本(2003)4)らは建替え後に オープンスペースの開放性や見守られる空間が減少しているとし ており，今後は計画段階で空間的なつながりに考慮し，主体を超 えた調整をするべきであると述べているなど，建替えによる集合 住宅団地の空間や緑環境の変容に着目した研究は蓄積されつつあ る。

以上のことから，高度経済成長期に建設されてきた大規模二ュ 一タウンは再生時期に差し掛かっており，ニュータウンの再生に おいて公園・緑地とともに良好な居住環境形成において重要な役 割を担う集合住宅団地内の緑地の保全·継承が課題となっており, 住宅更新に伴う団地内緑地の変化実態を明確にすることが求めら
れる。集合住宅団地内の緑地は，団地内外の居住者にとって身近 な緑地空間であり, 人々の利用などの様々な機能を有していると いえ，建替えに伴う緑地の変化を捉えるにあたって，量的な変化 に加えて, 機能的な変化も捉える必要があると考えられる。また, 千里ニュータウンでは従来, 公的主体による住宅団地供給が主で あったが, 近年の住宅更新に伴って供給主体が多様化しつつある。

そこで, 本研究では, 千里ニュータウン内の建替えられた住宅 団地が集積する地区を対象に, 供給主体別に建替え前後の緑地構 造の変化を量及び機能面で捉え, 建替えに伴う団地内の緑地整備 の課題を探ることを目的とした。

\section{2. 研究方法}

\section{（1）調査対象地の設定}

我が国に高度経済成長期以降に建設された大規模ニュータウン の中でも，近年，住宅更新が頻繁に行われている千里ニュータウ ンに着目し, 中でも, 民間分譫住宅の建替えが集積している新千 里東町地区(以下，新千里東町と呼ぶ) と公的賃貸住宅の建替えが 集積している佐竹台地区(以下, 佐竹台と呼ぶ)の 2 地区, 各地区 4 敷地，計 8 敷地を調査対象 に設定した。千里ニュータウ ン内の新千里東町, 佐竹台の 位置を図-1 に示し，表一 1 は各地区の調査対象敷地の 概要を示している。

新千里東町の 4 敷地は, 大 阪府豊中市に位置し，北大阪 急行線千里中央駅から約 200 〜 700m の徒歩圈内にある。 調査対象の 4 敷地は，建替え 前はいずれも大阪府住宅供給 公社分譲住宅であり，第一種

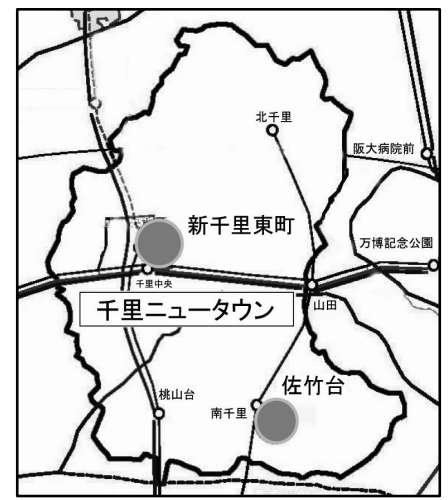

図-1 千里N内刀対象地区位置

*大阪府立大学大学院生命環境科学研究科 
中高層住居専用地域，建蔽率は $60 \%$, 容積率は $200 \%$ に指定され ている。建替え事業は, 2002～2003 年に実施され，建替え後は，い ずれも民間分譲住宅となり, 建替え前の戸数密度は各敷地で 108.8〜126.2 戸/ha であったが, 建替え後に196.5〜211.7 戸/ha と なり, 約 1.7〜1.9 倍に増加している。豊中市では, 2003 年に環 境配慮指針 5)を策定し，1,000 m²以上の開発に際して，例えば， 敷地面積 30,000 m²以上の場合，緑化面積 30\%以上の緑化義務を 課すとともに, 千里ニュータウン地区については, 2002 年に豊中 市千里ニュータウン地区住環境保全に関する基本方針 6)を策定し, 当該地に関わる指導として容積率の最高限度を $150 \%$, 建蔽率 の最高限度を $50 \%$ としている。但し, 敷地内空地の $30 \%$ 以上の緑 化, 全戸数の $100 \%$ 以上の駐車場設置義務等に加えて, 有効環境空 地の確保面積に基づいて容積率の割増し制度を運用しており,今回， 刘象とした 4 敷地は容積率が約180〜 195\%であり, いずれも容積 率の割増し制度の適用を受けている。なお, 䲞敷地に関してその 他, 地区計画や建築協定等による規制, 誘導は行われていない。

佐竹台の 4 敷地は, 犬阪府吹田市に位 置し，阪急電鉄北千里線南千里駅から約 100 600m の徒歩圈内にある。調查対 象の 4 敷地は, 建替え前大阪府住宅供給 公社賃貸住宅もしくは大阪府営住宅であり 第一種中高層住居専用地域，建蔽率は 60 \%，容積率は 200\%に指定されている。 建替え事業は，1990～92 年に敷地 C, D
から開始され，次いで敷地 B は 2003〜04 年，敷地A は 2005〜 08 年に実施され，建替え後も大阪府住宅供給公社賃貸住宅，大阪 府営住宅である。建替え前の戸数密度は各敷地で 71.1〜 134.0 戸 /ha であったが，建替え後に 106.5〜202.9 戸/ha となり，新千里 東町と同様に約 1.3 ～1.8 倍に増加している。吹田市では, 2004 年に吹田市開発事業に関する条例 7)を制定し, $500 \mathrm{~m}^{2}$ 以上の開発 に際して，例えば，敷地面積 $20,000 \mathrm{~m}^{2}$ 以上の場合，敷地面積の $30 \%$ 以上緑化義務を課すとともに, 千里ニュータウン地区につ いては，同じく 2004 年に千里ニュータウンのまちづくり指針 8) を策定し, 当該地に関わる指導として容積率の最高限度を $150 \%$, 建蔽率の最高限度を $50 \%$ とし, 敷地面積が $20,000 \mathrm{~m}^{2}$ 以上の場合, 有効空地率 $50 \%$ 以上確保することが指導されており, 敷地 $\mathrm{A} の み$ がこの条例や指針による指導を受けている。なお，敷地 $\mathrm{A}, \mathrm{C}$ で は建替え事業後の 2010 年に容積率の最高限度 $150 \%$, 建蔽率の 最高限度 $50 \%$ ，壁面の位置制限や建築物の形態や色彩，かき又は

査対象敷地の一覧

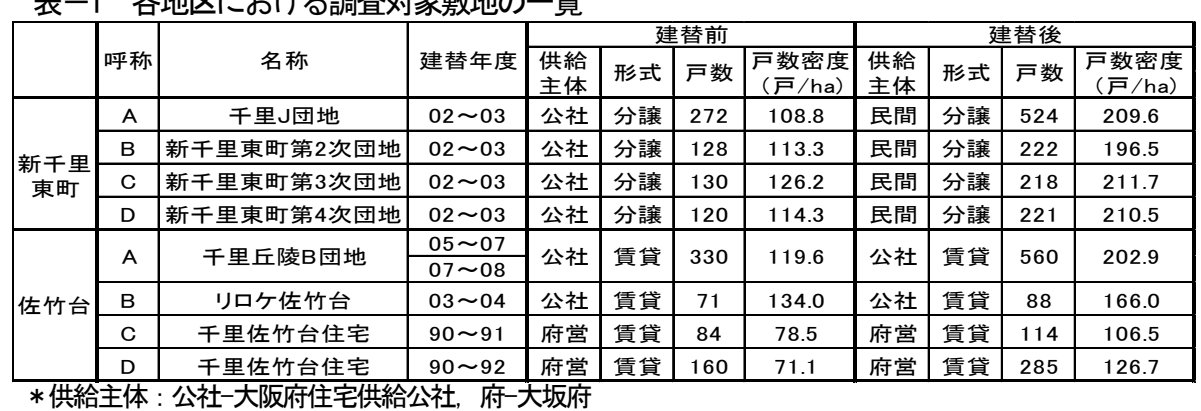

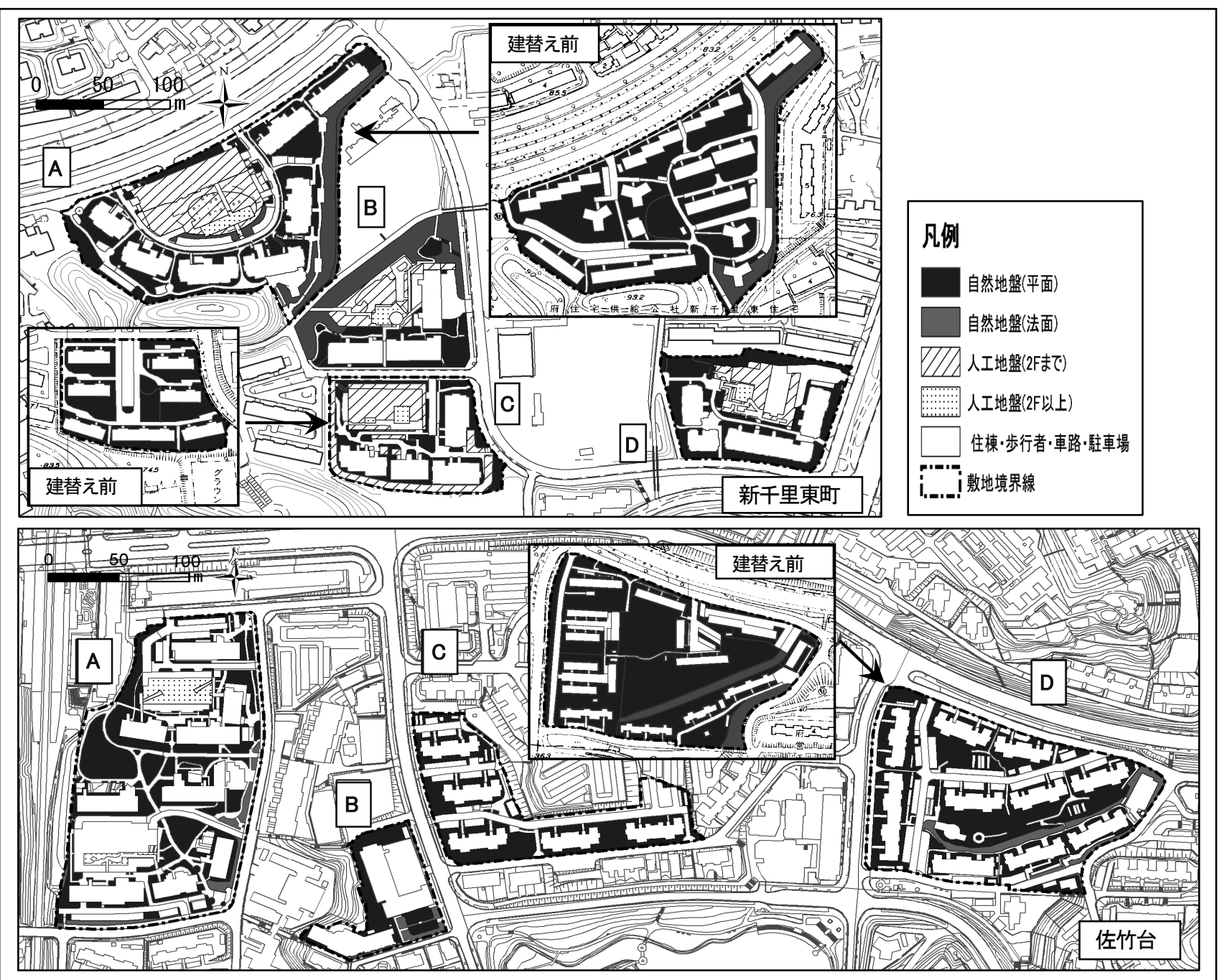

図一2 新千里東町, 佐竹台の建替え前後の地盤形態図 
さくの構造の制限等を規定した地区計画が定められた。

\section{（2）調査及び解析方法}

調査では, 建替え前後の 2 時期(建替え前 1986 年, 建替え後 2007 , 2008 年)の地形図(1/2500，1/500) と航空写真を用いて，各々の土 地利用(住棟，修景緑地，修景緑地(屋上)，広場，広場(屋上)，歩 行者路, 車路, 駐車場, その他), 緑被地(木本緑被, 草本緑被)を 特定し，ArcGISver.9.3 を用いて面積を計測した。なお，建替え 前の土地利用の広場は, 被覆状態が草本もしくは裸地でかつ歩行 者路に接続している空地とした。

解析では，建替え前後の緑地面積の量的変化は，地盤形態別緑 地面積, 緑被形態別緑被面積の 2 項目を設定し, 項目ごとの緑地 面積の変化を捉えた。次いで，機能的変化は，利用性，公開性， 視認性の 3 指標を設定し，指標別の緑地面積の変化を捉えた。な お，緑地面積の変化は，敷地面積に対寸る分類毎の緑地面積の割 合を算出し，その割合の増減で変化を捉えるものとした。各分類 の設定について具体に以下に詳述する。

量的変化の地盤形態別緑地面積は, 緑地を自然地盤(平面), 自 然地盤(法面)，人工地盤( $2 \mathrm{~F}$ まで)，人工地盤( $2 \mathrm{~F}$ 以上)の 4 つの地 盤形態で分類した。緑被形態別緑被面積は，木本と草本の緑被形 態別に捉えた。

機能的変化の利用性は，広場面積の増減で捉えるものとし，公 開性は，緑地を誰でも立ち入ることができる「開放」の緑地，居 住者以外の立入りを看板などの物理的な手段以外で制限している 「準閉鎖」の緑地，居住者以外の立入りを柵や電子ゲートなどの 物理的な手段で制限している「閉鎖」の緑地の 3 つに分類して捉 えた。なお，建替え後の公開性の評価については，2010 年 9 月 の現地調査を通じて把握し，また，同調査において周辺地区の大 阪府住宅供給公社分譲住宅，大阪府住宅供給公社賃貸住宅，大阪 府営住宅の緑地を見ると開放であることから建替え前の緑地はす べて開放であるものとした。視認性は, 緑地を敷地の外部から「見 える」緑地(視認範囲は直線距離で $20 \mathrm{~m}$ までとした), 外部から柵 などの「障害物越しに見える」緑地，外部から「見えない」緑地 の3つに分類して捉えた。なお，視認性の評価については，図上 調査及ひ現地での補足調査（2010 年 9 月）によって把握した。

\section{3. 結果及び考察}

\section{(1) 量的変化}

1）地盤形態別緑地面積

図一2 は, 新千里東町, 佐竹台の建替え前後の地盤形態図を示 している。なお，建替え前は，新千里東町では敷地 $\mathrm{A}, \mathrm{C}$, 佐竹 台では敷地 $\mathrm{D}$ の建替え前の代表例を示している。図一 3 は，建替 え前後の敷地全体に占める緑地面積の割合及び地盤形態別緑地面 積の敷地面積割合の集計結果を示している。

まず，図一 3 より，新千里東町における建替え前後の緑地面積 の変化を見ると, 建替え前の緑地面積は, 地区全体で $29,450 \mathrm{~m}^{2}$, $51.5 \%$ であり，建替え後の緑地面積も地区全体で $31,850 \mathrm{~m}^{2}$, $55.8 \%$ と建替え前後を比較して建替え後に $2,400 \mathrm{~m}^{2}$, 割合で $4.3 \%$ 微増している。次いで，建替え前後の地盤形態別の緑地面積の変 化を見ると, 図一 2 より建替え前の敷地 $\mathrm{C}$ では南面に平行に配置 された住棟間に自然地盤(平面)の緑地の広がりが確認できるもの の, 建替え後の敷地 C では, 自然地盤(平面)の緑地が減少し, 敷 地中央部に大規模な立体駐車場が整備され，その上部に人工地盤

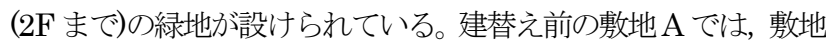
C と同様に住棟間に自然地盤(平面), 敷地東部に自然地盤(法面) の緑地が確認できる。一方, 建替え後の敷地 $\mathrm{A}$ では, 敷地東部の 自然地盤 (法面)の緑地は建替え前と同じく存在しているものの, 敷地 $\mathrm{C}$ と同様に敷地中央部に立体駐車場が整備され，その上部に 人工地盤 $(2 \mathrm{~F}$ まで)の緑地が整備されている。図一 3 より，地区全
体で地盤形態別緑地面積の変化を見ると, 自然地盤(平面)は, 建 替え後 $18.2 \%$ 減少寸るものの, 建替え前に存在していなかった人 工地盤 $(2 \mathrm{~F}$ まで)は，建替え後に $17.5 \%$ 増加している。また，自然 地盤(法面), 人工地盤( $2 \mathrm{~F}$ 以上)は, 建替え後に割合で $2.9 \%, 1.9 \%$ の微増にとどまっている。以上のことから，新千里東町では地区 全体での緑地面積量は建替え後に維持されているものの, 地区全 体で建替え後に自然地盤(平面)の緑地の減少が確認でき，人工地

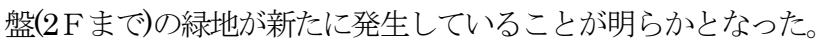

佐竹台における建替え前後の緑地面積の変化を見ると, 図一 3 より, 建替え前の緑地面積は 42,530 m², $64.3 \%$, 建替え後の緑 地面積は, 25,840 m², 39.1\% と建替え前後を比較して建替え後に 面積 $16,690 \mathrm{~m}^{2}$ ，割合で $25.2 \%$ も減少し，建替え後には建替え前 の約 6 割しか緑地が保有されていない。次いで，建替え前後の地 盤形態別の緑地面積の変化を見ると，図一2 より，建替え前の敷 地 Dでは, 住棟間と敷地中央部に自然地盤(平面)の緑地の広がりが 確認でき，敷地南東端部や敷地中央を東西に横断する自然地盤(法 面)の線状の緑地が確認できる。建替え後の敷地D では，特に敷地 中央部の自然地盤(平面)の緑地が建替え前の面的な広がりと比較し て減少し，敷地中央を東西に横断寸る自然地盤（法面）の緑地は確 認できるものの, 敷地東南端部の自然地盤（法面）の緑地は減少し ている。図一 3 より, 地区全体で地盤形態別緑地面積の変化を見る と，建替え後に自然地盤（平面）は約 $18 \%$ 減少し，建替え前には 存在していなかった人工地盤は建替え後に地区全体でわずか 1.7\%しか確認できない。

2) 緑被形態別緑被面積

図一 4 より，建替え前後の新千里東町での緑被面積の変化を見 ると，建替え前の緑被率は $50.8 \%$ であり，建替え後の緑被率も 8.5\%の減少に留まり $40.3 \%$ と維持されている。しかし, 緑被面 積の変化を緑被形態別に見ると，建替え前の木本の緑被率は $28.5 \%$ であったが, 建替え後の木本の緑被率は $12.2 \%$ と半減し, 一方, 草本の緑被率は, 建替え前 $22.3 \%$, 建替え後 $30.1 \%$ となり, 建替え後に $7.8 \%$ 増加している.

図一 4 より, 建替え前後の佐竹台での緑被面積の変化を見ると, 建替え前の緑被率は $59.2 \%$ であったが建替え後の緑被率は $32.1 \%$ と大幅に減少している。さらに, 緑被面積の変化を緑被形 態別に見ると, 建替え前の木本の緑被率は $18.9 \%$ であったが建替 え後の木本の緑被率は $12.8 \%$ と減少し, また，草本の緑被率の変 化を見ると, 建替え前に $40.3 \%$ であったものが建替え後に $19.3 \%$ と緑被率で $21.0 \%$ も減少し, 佐竹台では木本, 草本の緑被率がと もに減少していることが明らかとなった。

\section{（2）機能的変化}

1）利用性

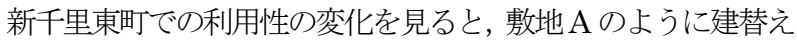

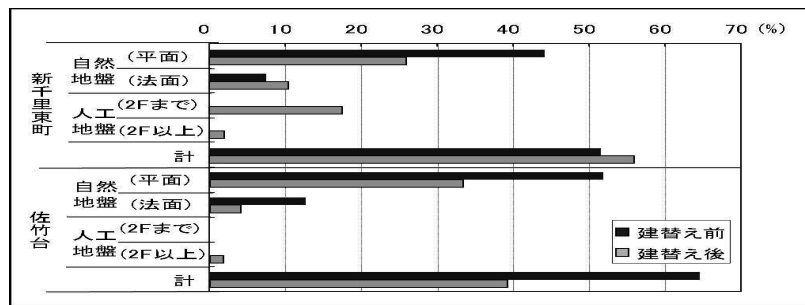

図－3 建替え前後の緑地面積及び地盤形態別緑地面積の敷地割合

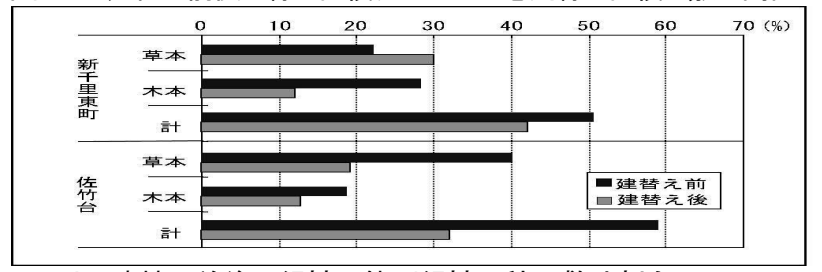

図－4＼cjkstart建替え前後の緑被形態別緑被面積の敷地割合 
後に敷地中央部に存在する人工地盤( $2 \mathrm{~F}$ まで)（図一2）が大きく まとまった広場となり，大規模な広場を有する敷地も存在する。 図一5 より, 地区全体での利用性変化を広場面積の敷地に占める 割合で見ると，建替え前の広場は割合で 3.0\%であったが建替え 後に割合で $14.3 \%$ と建替え前と比較して約 1 割増加している。以 上のことから, 新千里東町では, 地区全体で建替え後に広場面積 は増加し，利用性は高まったものと考えられる。

佐竹台での利用性の変化を見ると, 敷地 D では中央部の自然地 盤(平面)の緑地が建替え前には広場となっており, 敷地中央部に 大きくまとまった広場を有していたが，建替え後，住棟によって 広場となっていた自然地盤(平面) (図一2) の緑地が細分化され, 広場面積も減少している。図一 5 より，地区全体での利用性変化 を広場面積の敷地に占める割合で見ると，建替え前の広場は割合 で $21.0 \%$ であったが, 建替え後に割合で $12.1 \%$ と建替え前と比較 して約 1 割減少している。以上のことから，佐竹台では新千里東 町とは異なり建替え後, 緑地の利用性は低下したものと考えられ る。

\section{2）公開性}

新千里東町での公開性の変化を見ると, 敷地 $\mathrm{B}, \mathrm{D}$ のように, 建替え後に敷地中央部の人工地盤 $(2 \mathrm{~F}$ まで・ $2 \mathrm{~F}$ 以上)の緑地（図 -2）が閉鎖の緑地になっている敷地も存在する。図一 6 より，地 区全体で見ると開放の緑地は建替え前に $51.5 \%$ であったが建替 え後に $29.6 \%$ と建替え前と比較して約 2 割減少し, 一方, 建替え 前には存在しなかった準閉鎖の緑地が $9.1 \%$, 閉鎖の緑地が $17.0 \%$ と合わせて約 $25 \%$ 存在している。以上のことから, 新千里 東町では，建替え後に開放の緑地が建替え前と比較して減少し， 準閉鎖や閉鎖の緑地が新たに出現し，建替え後，緑地の公開性は 低下したものと考えられる。

一方，佐竹台での公開性の变化を見ると，図一6 より，開放の 緑地は建替え前に $64.3 \%$ であったが建替え後に $39.1 \%$ と減少す るものの，新千里東町で見られた閉鎖や準閉鎖の緑地は存在して いない。以上のことから，建替え後に開放の緑地が減少し，緑地 の公開性は低下寸るものの，建替え後も敷地内の緑地はすべて開 放の緑地となっており，建替え後に準閉鎖，閉鎖の緑地は発生し ていない。

3）視認性

図一7 より，新千里東町での視認性の変化を見ると，建替え後 に敷地外から「見える」緑地は，建替え前と比較して微减にとど まっており, 視認性に大きな変化は見られない。一方, 佐竹台で

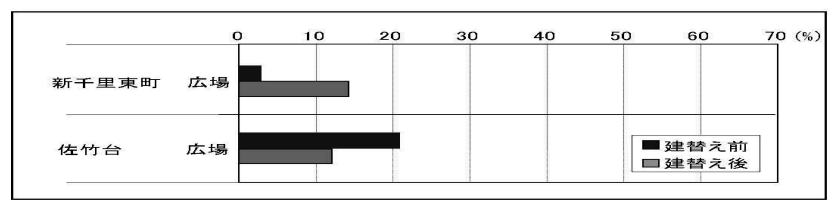

図－5 建替え前後の緑地の利用性評価面積の敷地割合

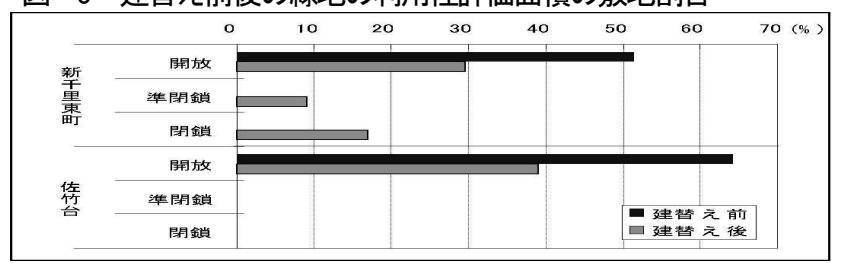

図一6 建替え前後の緑地の公開性評価面積の敷地割合

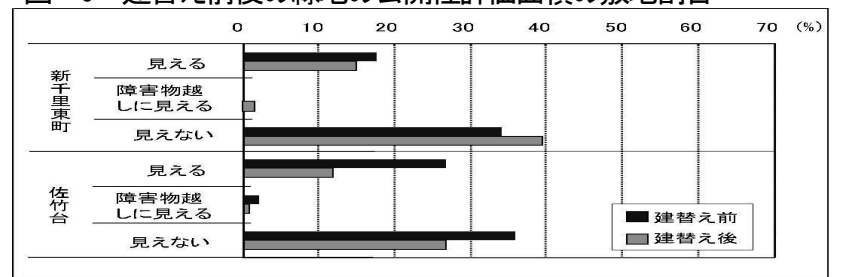

図－7建替え前後の緑地の視認性評価面積の敷地割合
は，敷地外から「見える」緑地は，建替え前に $26.6 \%$ であったが 建替え後に $11.7 \%$ と建替え前と比較して約 $15 \%$ 減少している。 以上のことから, 緑地の視認性は佐竹台で敷地内に保有された緑 地面積の減少に伴って低下しているものと考えられる。

\section{4. まとめ}

以上のことから，豊中市に位置し，駅から徒歩圈内に位置して いる新千里東町の民間分譲住宅の建替えでは，容積率の割増し制 度を適用し, 建替え後に緑地面積, 緑被率ともに建替え前の量的 に担保されているものの, 自然地盤の緑地や木本の緑被率が減少 し，人工地盤 $(2 \mathrm{~F}$ まで) の緑地や草本の緑被率が増加している ことが明らかとなった。また，機能面での変化では建替え後に広 場面積の増加に伴って利用性は高まるものの，準閉鎖や閉鎖の緑 地が増加し公開性が低下していることが明らかとなった。民間分 譲住宅の建替えでは, 容積と駐車台数の確保, 経済性の観点から, 立体駐車場の導入と人工地盤への屋上緑化が導入され, 草地が増 えている。一方で, 居住者のセキュリティの観点から河本ら 4)も 指摘するように緑地が周辺居住者に対して非公開となりや寸いも のと考えられる。従って，民間分譲住宅としての建替えでは，建 替え後に屋上緑化の導入によって緑地面積は保持され，利用性は 高まるものの, 閉鎖と準閉鎖の緑地の発生により公開性は低下し, 木本の緑被面積の大幅な減少によって，千里ニュータウンが継承 している緑地の質が低下寸る危険性が高く, また, 緑地の大半が 屋上緑化に依存していることから緑地の永続性も危惧される。よ って, 今後建替えに際して, 公開性を高めたり, 団地内で成長し てきた木本系の樹木を保全していくなどの質の向上が求められる。

一方，吹田市に位置し，新千里東町と同様に駅から徒歩圈内に 位置している佐竹台の公的賃貸住宅の建替えでは，新千里東町と は異なり，公社や府営といった貨貸住宅のため，経済的な制約か ら立体駐車場やその上部の屋上緑化の導入が見られず，敷地内の 緑地面積が減少し，ニュータウン内の緑地といら資産の低下を招 いており, 従前の緑地を保全することが求められる。また, 建替 え後に緑地面積が減少することで, 緑地の公開性, 利用性ともに 低下寸るものの，公共事業として緑地等の地域への公開性を確保 する観点から建替え前と同様に建替え後に確保された緑地はすべ て開放の緑地として維持されていることが先行研究 4) と同様に確 認できた。

本論では，建替えに伴う集合住宅団地内の緑地の変化を事例調 查を通じて, 事業主体や住宅の所有関係別の量的及ひ米能的変化 の実態を明確化した。今後は, ニュータウンの建設過程を通じて 団地内に造成されてきた緑地の形成過程や住区内の公共緑地体系 との連関性を踏まえ, 団地内に保全・継承された緑地や失われた 緑地，人工地盤等の新たに創出された緑地を評価していくことが 課題である。

\section{引用・参考文献}

1)大阪府・豊中市・吹田市・独立行政法人都市再生機構・大阪府住宅供給 公社・財団法人大阪府タウン管理財団 (2007) : 千里ニュータウン再生 指針

2）加我宏之・待井陽介・下村泰彦・増田昇(2004) : 既存樹木が保存された 建替団地における建替前後の団地空間に対する居住者の嗜好性の変容 に関する研究 : ランドスケープ研究 67(5), 697-702

3) 武田重昭・増田昇・永井心平・小木曽裕・村岡政子(2010): 利用実態力 ら捉えた団地屋外空間の活用による団地再生に関する研究:ランドスケ 一プ研究 73(5), 469-472

4)河本真希・木多道宏・舟橋國男・鈴木毅・李斌(2003) : 千里ニュータウ ンにおける住環境変容に関する研究一集合住宅の建替えによるオープン スペースの変化についてー: 都市住宅学 43 号, 120-125

5)豊中市(2003) : 環境配慮指針

6)豊中市(2002) : 豊中市千里ニュータウン地区住環境保全に関する基本方針 7)吹田市(2004): 吹田市開発事業に関寸る条例 8)吹田市(2004) : 千里ニュータウンのまちづくり指針 